\title{
REJOINDER TO PROFESSOR MALAWER'S NOTE
}

\section{JAMES D. GOODNOW*}

The importance of the study of the international legal environment for international business majors cannot be disputed. The only question to be raised is the extent to which international law should be incorporated in every international business student's curriculum (i.e., as a required course or as a portion of one or more existing international business courses). Most textbooks on international business, international marketing, or international management rightly devote at least a chapter to this topic.

However, my survey was concerned with the required content of international business courses for all business students regardless of major. With this point in mind, two points should be made. First, the survey's choice of words may have been misleading. Opinions were solicited on "international law and comparative national laws." It is possible that the respondents might have rated "international law" or "the legal environment of international business" relatively high; while "comparative national laws" would be considered a bit too detailed for the basic body of knowledge for students who are not preparing to be international business specialists. Second, many of the persons teaching international business have advanced degrees in economics or one of the functional areas of business and until recently have had a somewhat narrower view of the content of international business curricula. With the latter point in mind, Professor Malawer has served us well by pointing out the appropriate legal subtopics (some of which are relatively unique to many curricula in business) to be included in some phase of international business programs. Similar comments from scholars in political science, cultural anthropology, and sociology on the major subtopics from their respective disciplines which should be included in international business programs would also be most welcome. The direction of intellectual development among members of the Academy of International Business is apparently toward a more careful analysis of the legalpolitical and sociocultural aspects of our field. Hopefully, through guidance to AACSB and other interested groups, the business school curricula can be given enough flexibility so that both professors and students will be better able to analyze these nontraditional yet critically important components of the arenas in which international business strategies are planned and executed.

*Dr. Goodnow is Executive Secretary of the Academy of International Business. 